\title{
Economic Feasibility of Cooling Dry Cows: Findings and Spreadsheet ${ }^{1}$
}

\author{
Fernanda Ferreira, Geoffrey Dahl, and Albert De Vries ${ }^{2}$
}

\section{Heat Stress Affects Dry Cows}

The negative effects of heat stress in lactating cows are well known, but only recent studies have explored those effects along with the full benefits of cooling dry cows. Recent work at the University of Florida has demonstrated the benefits of dry cow cooling on calf performance and cow health in the next lactation. Dry cows that have received evaporative cooling and shade during the summer vs. dry cows that received shade only produced on average 11 $\mathrm{lb}$ per day ( $5 \mathrm{~kg}$ per day) more milk in the next lactation compared with those cows that were only under shade (do Amaral et al. 2009; Tao et al. 2011; Tao et al. 2012). Heat stress during the dry period negatively affects immunity and fertility of cows (do Amaral et al. 2011; Thompson and Dahl 2012). Reduced birth weights and growth rates in calves have also been reported (Collier et al. 1982; do Amaral et al. 2011; Tao et al. 2012). Cooling of dry cows, however, requires infrastructure and energy investments.

This document summarizes the results of our recent publication (Ferreira et al. 2016) that quantified the economic losses across the United States if dry cows were not cooled. This publication also summarizes the results of an economic feasibility analysis of investments in evaporative cooling (soakers and fans) and cooling barns for dry cows. This document also describes the spreadsheet that was developed for the analysis. The spreadsheet is available to readers who want to perform an economic analysis of cooling dry cows with their own data.

\section{Basic Assumptions}

In our study, we used weather data from the National Oceanic and Atmospheric Administration (NOAA) to calculate the annual number of heat stress days for each of the 50 US states. A day qualified as a heat stress day if the average Temperature Humidity Index (THI) was above 68. No seasonal calving was considered. On average, $15 \%$ of cows were assumed to be dry year-round. USDA-NASS (2016) statistics provided the number of dairy cows per state. Only multiparous cows were considered in the calculation because the effect of cooling prepartum heifers has not been quantified. Cows were assumed to be cooled during lactation, so the benefits of cooling dry cows would be fully expressed. If cows experienced heat stress every day during the dry period, they would produce $11 \mathrm{lb} /$ day $(5 \mathrm{~kg} /$ day) less milk in the next lactation.

The milk price in the calculation was $\$ 20 / \mathrm{cwt}(\$ 0.40 / \mathrm{kg}$, US five-year average) (Gould 2016), and feed cost was $\$ 0.13 / \mathrm{lb}$ of DMI $(\$ 0.28 / \mathrm{kg})$ (Rollin, Dhuyvetter, and Overton 2015). Thus, the milk income over feed cost (IOFC) was $\$ 14.90 /$ cwt of milk $(\$ 0.33 / \mathrm{kg})$.

1. This document is AN342, one of a series of the Department of Animal Sciences, UF/IFAS Extension. Original publication date March 2018. Visit the EDIS website at http://edis.ifas.ufl.edu.

2. Fernanda Ferreira, PhD candidate; Geoffrey Dahl, professor, department chair; and Albert De Vries, professor, Department of Animal Sciences; UF/IFAS Extension, Gainesville, FL 32611. 


\section{Economic Losses from Milk Production Due to Heat Stress}

Figure 1 shows the number of heat stress days per state and milk loss in the next lactation if dry cows are not cooled for the 25 largest dairy states in the US. States in the South have the greatest number of heat stress days per year, but even states like Wisconsin have a significant number of heat stress days throughout the year (75).

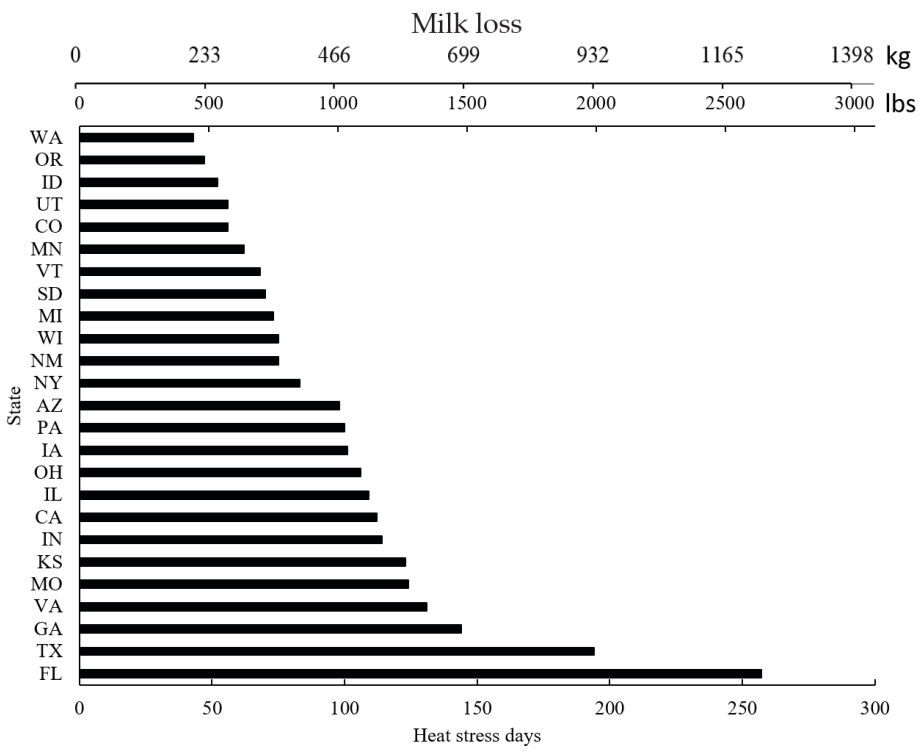

Figure 1. Milk lost per cow in the subsequent lactation (340 days) and days under heat stress for the top 25 states with the most dairy cows. We assumed an average loss of $11 \mathrm{lb}$ of milk ( $5 \mathrm{~kg}$ ) in the subsequent lactation for each day of heat stress if the cow was not cooled when dry.

Each day of heat stress represents a loss of $10.3 \mathrm{lb}$ of milk $(4.66 \mathrm{~kg})$ in the next lactation and economic losses of $\$ 0.91 /$ cow per day if dry cows are not cooled. For example, Florida has, on average, 257 days of heat stress per year. Therefore, if dry cows were not cooled, they would produce $2,647 \mathrm{lb}$ of milk $(1,201 \mathrm{~kg})$ less than their cooled herdmates (257 x $10.3 \mathrm{lb} /$ day), representing a loss of approximately $\$ 234$ per cow per year (\$0.91 x 257). We have also calculated the average number of heat stress days per year for the US, weighting the number of heat stress days per state by the number of cows per state. The average dairy cow in the US is subject to 96 heat stress days per year. This represents $988 \mathrm{lb}$ of milk $(448 \mathrm{~kg})$ less in the next lactation per cow. The results of this study showed a loss of $\$ 810$ million per year in the United States from lost milk production alone if dry cows were not cooled. The fraction of all dry cows that are cooled in the US is not known.

\section{Cooling Dry Cows: Investment, Utilities, Maintenance, and Feasibility Analysis}

To cool their dry cows with evaporative cooling, some farmers might need to build a barn with a cooling system, whereas others may only need to invest in the cooling system because a barn is already available. Therefore, the economic feasibility analysis considered these two possibilities separately. Cooling costs included expenses for electricity and water during heat stress days. All costs were prorated across 20 years, which is equal to the assumed lifespan of the barn (IRS 2017).

The default investment costs for building a barn were assumed to be $\$ 2,500$ per stall (Kammel 2015). This does not include the investment costs of fans and soakers. We assumed a residual value of $10 \%$ for the barn after 20 years. We also assumed that the cooling system within the barn consisted of fans ( $0.4 \mathrm{~kW}, 80 \mathrm{~cm}$, 7-year lifetime) and soakers, including water pipe (5-year lifetime). Each fan cost $\$ 700$ (Kammel 2015). We assumed five dry cow stalls per fan based on the setup at the University of Florida Dairy Unit, where most of the reviewed dry cow cooling studies have taken place. During the 20 -year period, fans were purchased at the start of years 1,8 , and 15 , which can be seen on the cash flow part of the spreadsheet. We assumed a residual value of $10 \%$ and straight-line depreciation. Therefore, the remaining value per fan was $\$ 160$ in year 20. The cost of the soakers was based on Dhuyvetter et al. (2000), adjusted for inflation (DOL 2015), and assumed to be $\$ 8.19$ per stall. Soakers were purchased four times during the 20 years (years 1, 6, 11, and 16). The remaining value was $\$ 0.80$ per stall.

\section{Utilities}

We calculated the fixed and variable costs of energy and water. Nonresidential water and energy prices were taken from GRU (2015) and Dhuyvetter et al. (2000) and were corrected for inflation. Energy cost was divided into demand (fixed) and electricity (variable) charges, which were set at $\$ 37$ and $\$ 1.62$ per fan per heat stress day, respectively. We assumed that the energy efficiency of the fans was 0.75 $\mathrm{kW}$, and a fan ran for 24 hours during a heat stress day. The cost of water was $\$ 0.42$ per 264.17 gallons $(1,000 \mathrm{~kg})$. We assumed 15 gallons $(56.8 \mathrm{~kg})$ of water per stall per heat stress day to cool a dry cow. 


\section{Maintenance}

We assumed a sand maintenance cost of $\$ 90$ per dry cow stall per year when a new barn was built. The maintenance cost of fans and soakers was set at $\$ 15$ per fan per year based on the setup at the University of Florida Dairy Unit.

\section{Feasibility Analysis}

Cash flow during the 20-year period was discounted at an annual rate of 5\%. We calculated the Net Present Value (NPV) of investment in dry cow cooling per cow per year. The NPV is the value of the investment in today's dollars compared with the next best alternative for this money, assuming a 5\% interest rate. An NPV greater than $\$ 0$ means that the investment is the best decision. The time needed to pay off the initial investment (payback period) and the benefit-cost ratio (BCR) were also calculated. Short payback periods and BCRs greater than 1 mean that the investment is profitable. Separate analyses were carried out for investments with and without barn construction.

We performed breakeven analyses for milk price, increase in milk production in the subsequent lactation, and barn investment cost per dry cow stall, for a payback period of 3 years for the top 3 states with the most dairy cows (California, Wisconsin, and New York), and for Florida and Texas, which are among the top 25 states for number of dairy cows and have a high number of heat stress days annually. For each variable that we changed, we kept the other variables at their default values (i.e., $\$ 20 / \mathrm{cwt}(\$ 0.44 / \mathrm{kg})$ milk price, $11 \mathrm{lb}$ per day ( $5 \mathrm{~kg}$ per day) increase in milk production in the subsequent lactation, $\$ 2,500$ per stall barn investment cost). We also varied milk price ( $\$ 15.40, \$ 20$, and $\$ 24.50$ / cwt of milk ( $\$ 0.34, \$ 0.44$, and $\$ 0.54 / \mathrm{kg})$ ), potential increase in milk production in the subsequent lactation $(2.2 \mathrm{lb}, 6.6$ $\mathrm{lb}$, and $11 \mathrm{lb}$ per day $(1,3$, and $5 \mathrm{~kg}$ per day)), and investment costs per dry cow stall $(\$ 1,500, \$ 2,500$, and $\$ 3,500)$ to determine their effects on the NPV per cow per year when the number of heat stress days was varied from 0 to 360 .

\section{Economic Spreadsheet to}

\section{Calculate the Feasibility of Cooling Dry Cows}

We developed an economic spreadsheet for the feasibility analysis of cooling dry cows. The spreadsheet is available at http://dairy.ifas.ufl.edu/tools. The spreadsheet contains the default inputs for Florida. Users can change prices and other inputs to run their own economic feasibility analysis.

\section{All Regions Benefit from Dry Cow Cooling}

Generally, cooling of dry cows was found to be very profitable. If we consider the average number of heat stress days in the US (96), the default milk price, increase in milk production in the next lactation if dry cows are cooled, and barn cost per stall, the NPV for an average cow per year is $\$ 22.50$. The payback period is 5.67 years, and the BCR is 1.45. In this situation, it would be profitable for $89 \%$ of the dairy cows in the US to be cooled in a new dry cow barn.

The profitability depends on milk price, and milk price should be taken into consideration when a barn needs to be built to house the dry cows (Figure 2). However, scenarios in which milk price is low (such as $\$ 13.50 /$ cwt $(\$ 0.34 / \mathrm{kg})$ ) can be profitable if the number of heat stress days is moderate (more than 100), or if the costs of building a new barn are lower ( $\$ 2,345$ per stall). Obviously, the payback period in this scenario is longer (around 11 years), and the BCR is much smaller (1.15), but it is still greater than 1. However, $47 \%$ of the cows in the US are located in states with more than 100 heat stress days per year and would benefit from cooling during their dry period, even in low milk price scenarios. The only scenario that may not be profitable is investing in cooling dry cows when minimal improvements in milk production are expected. However, studies have consistently shown a moderate to large increase in milk yield (Ferreira et al. 2016).

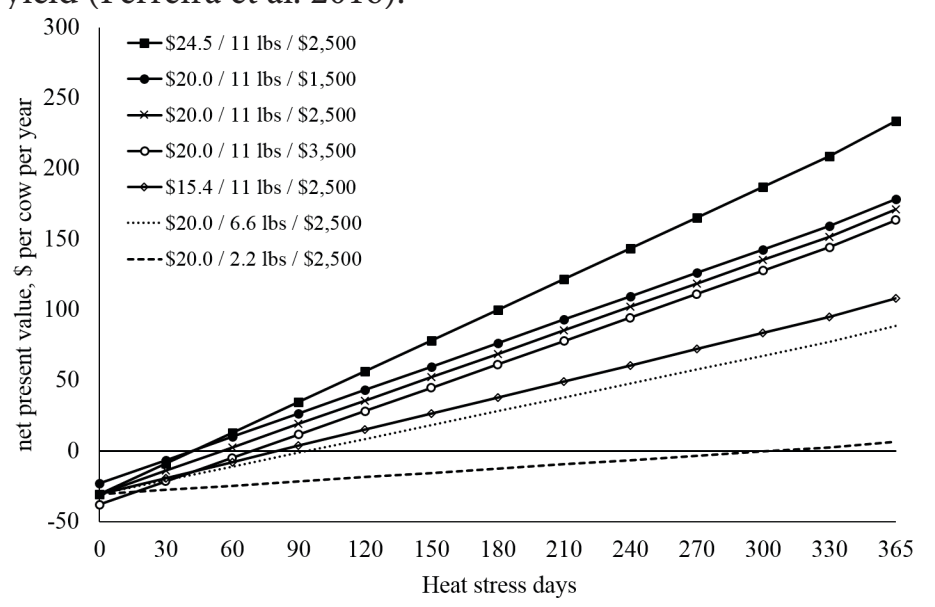

Figure 2. Net present value per cow per year for 0 to 360 days of heat stress per year. Fan, soaker, and barn investment costs were included. Milk prices, \$ per cwt (\$ per kg): \$15.40, $\$ 20.00$, and $\$ 24.50$ (\$0.34, $\$ 0.44$, and $\$ 0.54)$. Increase in milk yield, lb per day (kg per day): 2.2 , 6.6 , and $11(1,3$, and 5). Barn investment cost (\$ per dry cow stall): $\$ 1,500, \$ 2,500$, and $\$ 3,500$.

Credits: Ferreira et al. (2016)

If dry cows are already housed in a barn and the only investment required is the cooling system, then cooling dry cows is profitable in most scenarios and in all the 50 states we have studied (Figure 3). This applies even when milk 
price and improved milk production in the next lactation are very low $(\$ 13 /$ cwt $(\$ 0.34 / \mathrm{kg})$ or $2.2 \mathrm{lb} /$ day $(1 \mathrm{~kg} /$ day $))$.

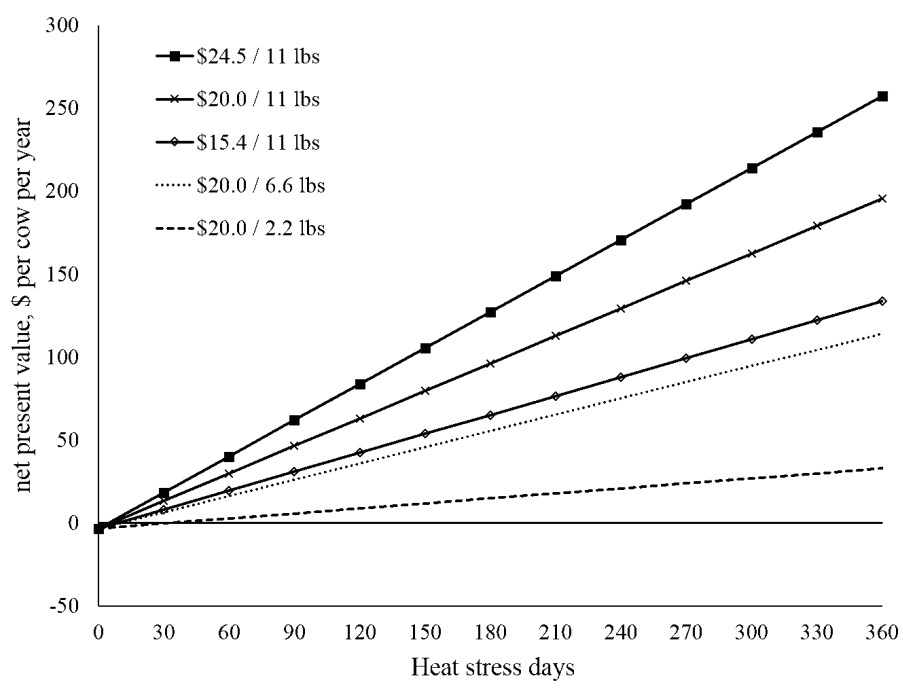

Figure 3. Net present value per cow per year for 0 to 360 days of heat stress per year. The costs of fans and soakers are included, but barn investment costs are not. Milk prices, \$ per cwt (\$ per kg): \$15.40, $\$ 20.00$, and $\$ 24.50(\$ 0.34, \$ 0.44$, and $\$ 0.54)$. Increase in milk yield, lbs per day (kg per day): 2.2, 6.6, and 11 (1,3, and 5).

Credits: Ferreira et al. (2016)

\section{Other Considerations}

In this study, we only included effects of heat stress on milk production in the subsequent lactation. Other benefits of cooling dry cows were not included in our analysis. Heat stress during the dry period shortens gestation length (Tao and Dahl 2013). In addition, heat stress increases the number of stillbirths (Vieira-Neto et al. 2017) and the incidence of postpartum diseases (Adin et al. 2009). The immune function is compromised in cows that experience heat stress during the dry period (do Amaral et al. 2011). Milk fat might also decrease (Avendaño-Reyes et al. 2006; do Amaral et al. 2009). Heat stressed cows had increased days to pregnancy diagnosis during the first 150 days in the subsequent lactation relative to dry cows during cool months (Thompson and Dahl 2012). Calves born from cows exposed to heat stress during their dry period also had lower birth weights and compromised passive immune transfer (Tao et al. 2012). The economic implications of these effects are meaningful but not included in our economic analysis. Therefore, the economic benefits from cooling dry cows in this study appear to be conservative.

\section{References}

Adin, G., A. Gelman, R. Solomon, I. Flamenbaum, M. Nikbachat, E. Yosef, A. Zenou, et al. 2009. "Effects of cooling dry cows under heat load conditions on mammary gland enzymatic activity, intake of food and water, and performance during the dry period and after parturition.” Livestock Science 124: 189-195. http://dx.doi.org/10.1016/j. livsci.2009.01.014.

Avendaño-Reyes, L., F. D. Alvarez-Valenzuela, A. CorreaCalderón, J. S. Saucedo-Quintero, P. H. Robinson, and J. G. Fadel. 2006. "Effect of cooling Holstein cows during the dry period on postpartum performance under heat stress conditions." Livestock Science 105: 198-206. http://dx.doi. org/10.1016/j.livsci.2006.06.009.

Dhuyvetter, K. C., T. L. Kastens, M. J. Brouk, J. F. Smith, and J. P. Harner. 2000. "Economics of cooling cows." Heart of America Dairy Management Conf., St. Joseph, MO.

do Amaral, B. C., E. E. Connor, S. Tao, J. Hayen, J. Bubolz, and G. E. Dahl. 2009. "Heat-stress abatement during the dry period: Does cooling improve transition into lactation?" Journal of Dairy Science 92: 5988-5999. http://dx.doi. org/10.3168/jds.2009-2343.

do Amaral, B. C., E. E. Connor, S. Tao, M. J. Hayen, J. W. Bubolz, and G. E. Dahl. 2011. "Heat stress abatement during the dry period influences metabolic gene expression and improves immune status in the transition period of dairy cows." Journal of Dairy Science 94: 86-96. http:// dx.doi.org/10.3168/jds.2009-3004.

DOL (Department of Labor). 2015. U.S. Bureau of Labor Statistics. Accessed on May 26, 2016. https://data.bls.gov/ cgi-bin/cpicalc.pl

Ferreira, F. C., R. S. Gennari, G. E. Dahl, and A. De Vries. 2016. "Economic feasibility of cooling dry cows across the United States." Journal of Dairy Science 99: 9931-9941.

Gould, B. W. 2016. "Milk prices.” Understanding Dairy Markets. Accessed on May 26, 2016. http://future.aae.wisc. edu/data/annual_values/by_area/10?tab=prices

IRS (Internal Revenue Service). 2017. "Depreciation, depletion, and amortization." Publication 225 (2017), Farmer's Tax Guide. Accessed on February 16, 2018. https://www.irs. gov/publications/p225/ch07.html

Kammel, D. W. 2015. "Building cost estimates-Dairy modernization." University of Wisconsin-Extension Dairy Team. Accessed on May 26, 2016. http://fyi.uwex. edu/dairy/files/2015/11/Building-Cost-Estimates-DairyModernization.pdf 
NOAA (National Oceanic and Atmospheric Administration). 2015. National Centers for Environmental Information. Accessed on May 26, 2016. http://www.ncdc.noaa.gov/

NRC. 2001. Nutrient Requirements of Dairy Cattle. $7^{\text {th }}$ edition. Washington, D.C.: The National Academies Press.

Rollin, E., K. C. Dhuyvetter, and M. W. Overton. 2015. "The cost of clinical mastitis in the first 30 days of lactation: An economic modeling tool." Preventive Veterinary Medicine 122: 257-264. http://dx.doi.org/10.1016/j. prevetmed.2015.11.006.

Tao, S., J. W. Bubolz, B. C. do Amaral, I. M. Thompson, M. J. Hayen, S. E. Johnson, and G. E. Dahl. 2011. "Effect of heat stress during the dry period on mammary gland development." Journal of Dairy Science 94: 5976-5986. http:// dx.doi.org/10.3168/jds.2011-4329.

Tao, S. and G. E. Dahl. 2013. "Invited review: Heat stress impacts during late gestation on dry cows and their calves." Journal of Dairy Science 96: 4079-4093. http://dx.doi. org/10.3168/jds.2012-6278.

Tao, S., I. M. Thompson, A. P. A. Monteiro, M. J. Hayen, L. J. Young, and G. E. Dahl. 2012. "Effect of cooling heat-stressed dairy cows during the dry period on insulin response." Journal of Dairy Science 95: 5035-5046. http:// dx.doi.org/10.3168/jds.2012-5405.

Thompson, I. M. and G. E. Dahl. 2012. "Dry-period seasonal effects on the subsequent lactation." Professional Animal Scientist 28: 628-631. http://dx.doi.org/10.15232/ S1080-7446(15)30421-6.

Thompson, I. M. T., S. Tao, A. P. A. Monteiro, K. C. Jeong, and G. E. Dahl. 2014. "Effect of cooling during the dry period on immune response after Streptococcus uberis intramammary infection challenge of dairy cows." Journal of Dairy Science 97: 7426-7436. http://dx.doi.org/10.3168/ jds.2013-7621.

USDA-NASS. 2016. “Milk production.” Understanding Dairy Markets. Accessed on May 26, 2016. http://future.aae. wisc.edu/data/monthly_values/by_area/3712?area=US

Vieira-Neto, A., K. N. Galvão, W. W. Thatcher, and J. E. P. Santos. 2017. "Association among gestation length and health, production, and reproduction in Holstein cows and implications for their offspring." Journal of Dairy Science 100: 3166-3181. 